\title{
SARS-CoV-2-associated gastrointestinal and liver diseases: what is known and what is needed to explore
}

\author{
Dina Sweed ${ }^{1 *}$ (D) Eman Abdelsameea ${ }^{2}$, Esraa A. Khalifa ${ }^{3}$, Heba Abdallah ${ }^{4}$, Heba Moaz ${ }^{5}$ Inas Moaz ${ }^{6}$, \\ Shimaa Abdelsattar ${ }^{7}$, Nadine Abdel-Rahman $^{8}$, Asmaa Mosbeh $^{1}$, Hussein A. Elmahdy ${ }^{9}$ and Eman Sweed ${ }^{10}$
}

\begin{abstract}
Background: The pandemic of COVID19 which is caused by severe acute respiratory syndrome coronavirus 2 (SARS-CoV-2) was first described in China as an unexplained pneumonia transmitted by respiratory droplets. Gastrointestinal (GI) and liver injury associated with SARS-CoV-2 infection were reported as an early or sole disease manifestation, mainly outside China. The exact mechanism and incidence of Gl and liver involvement are not well elucidated.

Main body: We conducted a PubMed search for all articles written in the English language about SARS-CoV-2 affecting the $\mathrm{Gl}$ and liver. Following data extraction, 590 articles were selected. In addition to respiratory droplets, SARS-CoV-2 may reach the Gl system through the fecal-oral route, saliva, and swallowing of nasopharyngeal fluids, while breastmilk and blood transmission were not implicated. Moreover, Gl infection may act as a septic focus for viral persistence and transmission to the liver, appendix, and brain. In addition to the direct viral cytopathic effect, the mechanism of injury is multifactorial and is related to genetic and demographic variations. The most frequently reported Gl symptoms are diarrhea, nausea, vomiting, abdominal pain, and bleeding. However, liver infection is generally discovered during laboratory testing or a post-mortem. Radiological imaging is the gold standard in diagnosing COVID-19 patients and contributes to understanding the mechanism of extra-thoracic involvement. Medications should be prescribed with caution, especially in chronic Gl and liver patients.
\end{abstract}

Conclusion: GI manifestations are common in COVID-19 patients. Special care should be paid for high-risk patients, older males, and those with background liver disease.

Keywords: COVID-19, Gastrointestinal, Liver, Pathophysiology, SARS-CoV-2

\section{Background}

The pandemic of the novel 2019 coronavirus disease (COVID-19) started in December 2019 with an outbreak of unexplained pneumonia in Wuhan, China. Severe acute respiratory syndrome coronavirus 2 (SARS-CoV-2) is primarily transmitted by droplets and aerosols, affecting the respiratory system [1]. In the USA, the first case of SARS-CoV-2-associated

\footnotetext{
* Correspondence: dina.sweed@liver.menofia.edu.eg

${ }^{1}$ Pathology Department, National Liver Institute, Menofia University, Shibin El Kom 32511, Egypt

Full list of author information is available at the end of the article
}

gastrointestinal (GI) symptoms had a 2-day history of nausea and vomiting, then progressed to diarrhea upon hospital admission [2]. Subsequently, many studies reported GI and liver infection as the first presentation of COVID-19 with later (or no) respiratory symptoms [3]. This review summarizes the demographic, clinical manifestation, radiological, and pathological findings in COVID-19 patients presenting with GI symptoms to elucidate the route of transmission and mechanism of injury and provide guidance on GI and hepatic treatment in COVID-19 patients.

\section{Springer Open}

() The Author(s). 2021 Open Access This article is licensed under a Creative Commons Attribution 4.0 International License, which permits use, sharing, adaptation, distribution and reproduction in any medium or format, as long as you give appropriate credit to the original author(s) and the source, provide a link to the Creative Commons licence, and indicate if changes were made. The images or other third party material in this article are included in the article's Creative Commons licence, unless indicated otherwise in a credit line to the material. If material is not included in the article's Creative Commons licence and your intended use is not permitted by statutory regulation or exceeds the permitted use, you will need to obtain permission directly from the copyright holder. To view a copy of this licence, visit http://creativecommons.org/licenses/by/4.0/. 


\section{Main text}

\section{Material and methods}

A thorough PubMed search of all English-language articles published and in-press from December 2019 to December 2020 was done. The search terms were "COVID-19," "SARS-CoV-2," "gastrointestinal," "liver," "diarrhea," "abdominal pain," "nausea," "vomiting," "histopathology," "radiology," "pharmacology," and "liver enzymes." A total of 2160 studies were included in complete data extraction, and a final 590 papers were selected. The papers were reviewed, and data were collected and analyzed by gastroenterology and hepatobiliary specialists.

The mode of transmission of SARS-CoV-2-induced GI and liver diseases

Although inhalation of respiratory droplets is the primary mechanism of SARS-CoV-2 transmission, fecaloral transmission may be an additional source of GI infection, mainly in children. SARS-CoV-2 viral RNA was detected in the fecal matter for 11.2 to 33 days following viral clearance from the respiratory tract, indicating viral replication in the enterocytes and possible fecal-oral transmission [4]. Saliva and vomit were two additional routes of transmission. SARS-CoV-2 may infect the salivary gland by binding to and secreting from the angiotensin-converting enzyme 2 (ACE2) receptor. Therefore, saliva may play a role in the early stage of viral transmission [5]. The vomit also included viral particles either from nasopharyngeal fluids or the GI tract. The risk of viral transmission is positively correlated with vomiting severity [6]. Portincasa et al. suggest an unconfirmed hypothesis that the virus could translocate from the gut lumen into the liver via portal flow, negatively affecting hepatic cells [7]. SARS-CoV-2 could also reach the appendix via oropharyngeal contamination or appendicolith, resulting in bacterial translocation and appendicitis [8].

One study reported the possibility of SARS-CoV-2 transmission through breastmilk. However, the remaining studies did not find viral transmission in breastmilk, which is supported by the World Health Organization (WHO) that ensured breastfeeding was safe given proper precautions [9]. The low viral load in infected patients' serum makes this transmission route limited or even non-existent [10].

\section{Mechanism of SARS-CoV-2-induced GI and liver diseases}

(Fig. 1)

\section{Genetic factors}

The presence of four primary intestinal transcription factors, caudal type homeobox transcription factor 2 (CDX2), hepatocyte nuclear factor 4 (HNF4), mothers against decapentaplegic homolog 4 (SMAD4), or GATA in the intestine, modulates the function and activity of ACE2 and transmembrane protease serine 2 (TMPR SS2). These results could explain the population's

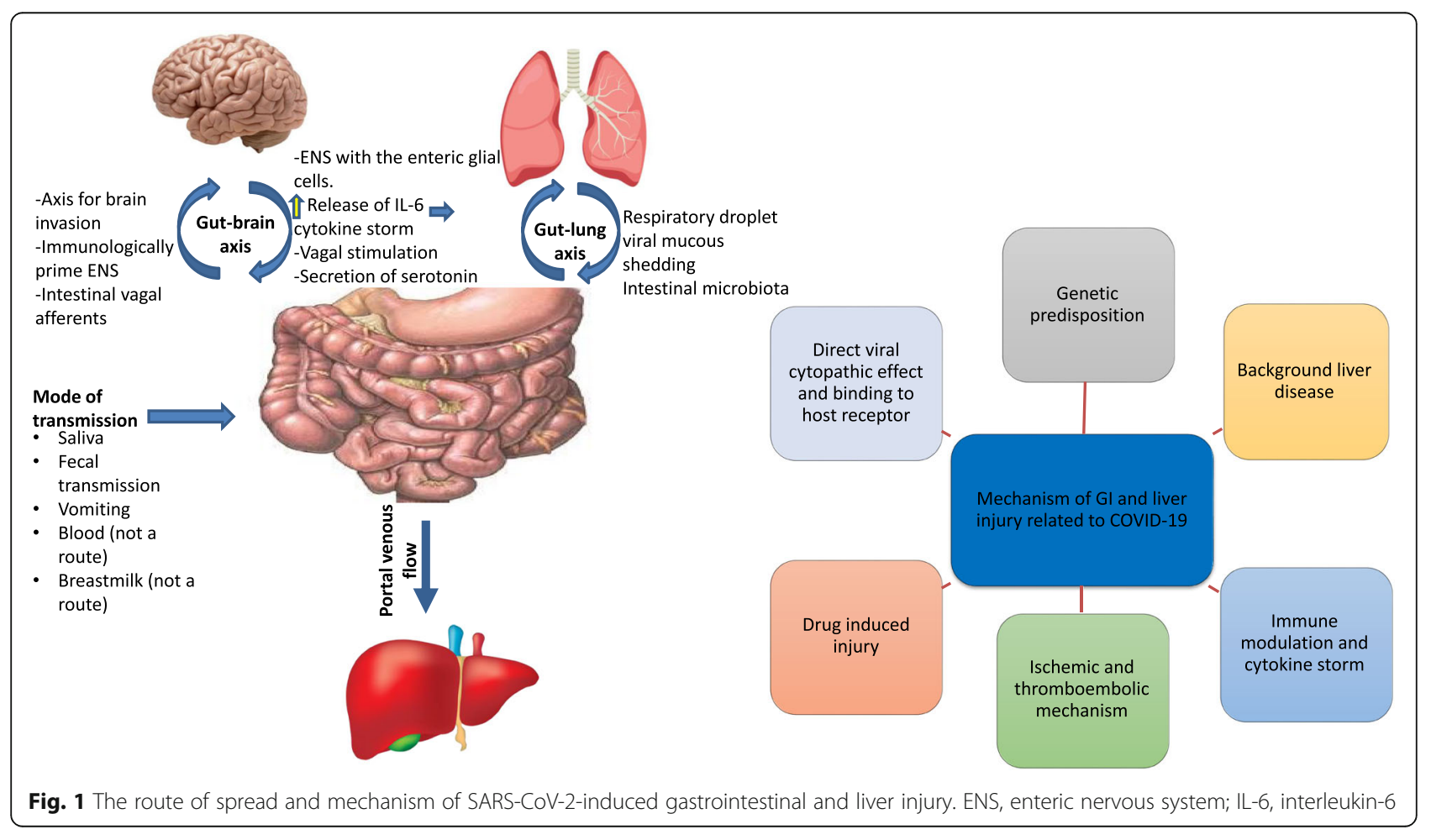


variable susceptibility to GI symptoms and severity of SARS-CoV-2 infection [11].

\section{Central-neurological mechanism}

The gut-brain axis may be a path for SARS-CoV-2 to invade the brain, ascend to the central nervous system (CNS) through intestinal vagal afferents, and immunologically prime the enteric nervous system (ENS). The ENS is strictly interconnected to the enteric glial cells (EGCs), which defend against gut pathogens by activating the Toll-like receptors (TLRs) and other inflammatory mediators. Conversely, SARS-CoV-2 neuroinvasion stimulates serotonin release and provides an alternative central mechanism for GI symptoms [12].

\section{Local mechanisms}

Viral-host receptor binding mechanism Coronaviruses are a group of single-stranded enveloped RNA viruses that express four structural proteins: spike glycoprotein, small envelope protein, matrix protein, and nucleocapsid protein, in addition to 16 non-structural proteins [13]. SARSCoV-2 enters host cells through the interaction between the envelope-anchored viral spike protein and the ACE2 host receptors. ACE2 receptors are widely expressed in various human cells, including the lungs, small intestine, colon, pancreatic islets, kidney, brain, vascular endothelium, and smooth and cardiac muscle [14].

SARS-CoV-2 has a unique structural and functional $\mathrm{S}$ protein that facilitates viral entry and replication. The high binding affinity of SARS-CoV-2 for human ACE2, 10-20-fold higher than SARS, increases the viral infectivity [15]. Besides, other host receptors for SARS-CoV-2, specifically CD147, TMPRSS2, endosomal cysteine proteases cathepsin $B$ and $L(C a t B / L)$, and furin, are widely distributed in multiple organs, enhancing viral binding and entry. The mechanism of SARS-CoV-2 binding to and entering host cells is illustrated in Fig. 2.

Gut microbiota The gut-lung axis is a bi-directional network in which many respiratory infections often accompany GI symptoms and vice versa. The gut microbiome plays a crucial role in modulating the immune response of SARS-CoV-2 patients to prevent vital organ damage. Alterations to the intestinal microbiota, in conjunction with an impaired immune system, contribute to COVID-19 patients' delayed recovery and mortality [16]. Re-formulating the gut microbiota through nutritional therapy, probiotics, or fecal microbiota transplantation (using standard guidelines) may emerge as a new therapeutic target in disease management $[16,17]$.

Hypochlorhydria Price suggests that the acidic $\mathrm{pH}$ of the normal gastric mucosa inactivates coronaviruses, explaining why the intestinal manifestation is more pronounced than the gastric ones [18]. However, more studies are recommended to evaluate the viral ability to survive and replicate through the extremes of GI pH.

\section{Systemic mechanisms}

Immune-related injuries Severe SARS-CoV-2 infection results in a clinical state resembling sepsis due to the massive release of cytokines by the immune system. This cytokine storm involves innate and cellular immunity, including activation of intrahepatic CD4+ and CD8+Tcells, Kupffer cells, activation of B cells, and anti-viral antibodies. These pathways progress toward apoptosis and necrosis of infected cells, resulting in multi-organ failure late in the course of disease [19].

Ischemia-reperfusion injury Severe SARS-CoV-2 cases suffer from ischemia-reperfusion injury through

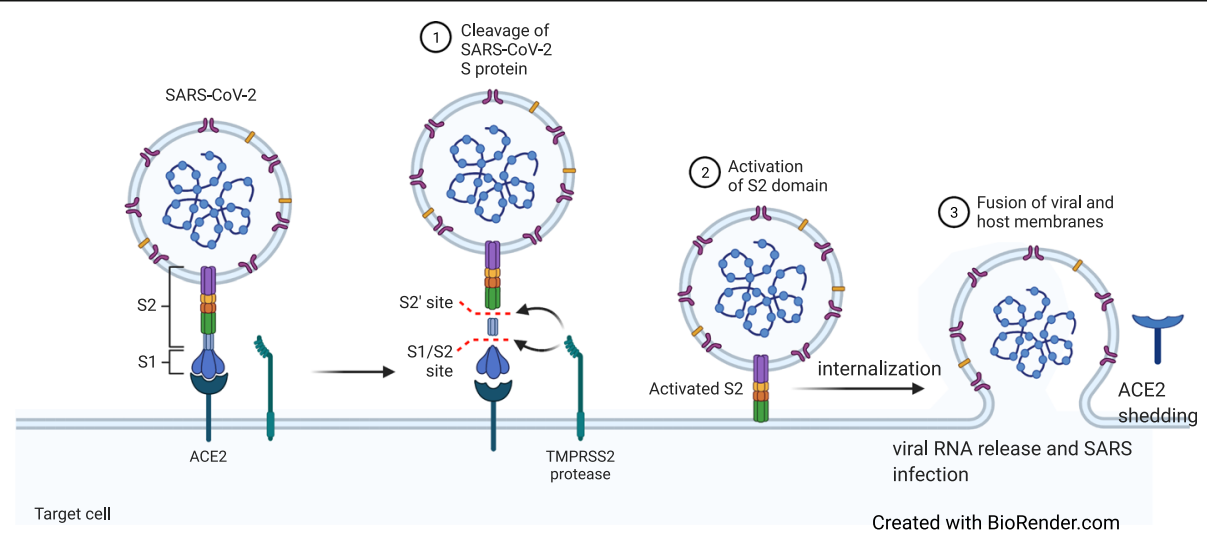

Fig. 2 Coronavirus uses angiotensin-converting enzyme-2 (ACE2) receptor to reach the cells with the binding of the viral spike (S) glycoprotein to cellular receptors via S protein priming by host cell proteases. TMPRSS2, transmembrane protease, serine 2; SARS-CoV-2, severe acute respiratory syndrome coronavirus 2 
activation of systemic inflammatory response syndrome (SIRS), SARS, or as a complication of sepsis and hypertension [3].

Drug-induced GI and liver disease Drug therapies for managing SARS-CoV-2 infection are reported to be a direct insult to the GI and liver in variable doses and conditions, discussed in a later section.

Symptoms and signs of GI injury in COVID-19 In a series of $>20,000$ hospitalized patients in the UK, the main symptoms of COVID-19 were respiratory (71.6\%), followed by enteric symptoms (nausea, abdominal pain, vomiting, and diarrhea) (29\%), with $4 \%$ of patients complaining of enteric symptoms alone [20]. Patients with GI symptoms experiencing a prolonged period between the onset of symptoms and viral clearance were more likely to have a positive stool test for the virus $(73.3 \%$ compared to $14.3 \%$ with no GI symptoms, $\mathrm{p}=0.033$ ) [21]. The prevalence of diarrhea was $5-10.3 \%$, nausea and vomiting $5.2-11.7 \%$, abdominal pain $2.7-8.8 \%$, and loss of appetite $15.8 \%$, with few reported cases of GI bleeding [22, 23].

There is no unique esophageal symptom associated with SARS-CoV-2 except for heartburn. Heartburn needs a standard treatment approach with $\mathrm{H} 2$ receptor antagonists or proton pump inhibitors (PPIs) [24]. Anorexia is one of the most frequent symptoms reported in COVID-19 patients, mainly associated with malaise and systemic inflammation [25].

Diarrhea may have been the only presentation in $16 \%$ of cases [26]. The diarrhea symptoms might last from 1 to 14 days with a mean of $5.4 \pm 3.1$ days, and the majority of patients experiencing self-limited diarrhea [21]. The possible mechanisms are direct interaction with ACE2 receptors or medications [26].

Epigastric pain, stomachache, and abdominal discomfort have been used to describe abdominal pain [27], and such pain may be a sign of gut nerve inflammation and precede the respiratory symptoms or be the sole manifestation of COVID-19. However, there was no reported data on the quality or nature of the pain characteristic of COVID-19.

Gastrointestinal bleeding in patients with COVID-19 is not as common as other GI symptoms, with a frequency ranging from 4 to $13.7 \%$. A review of 2023 patients with COVID-19 reported only two GI bleeding cases across 15 studies [28]. The cause of bleeding is often not determined, and most patients were treated conservatively. Lower GI bleeding has also been reported in association with COVID-19, necessitating urgent consultation [29]. Ischemia may be the result of thrombotic dysfunction, hypoperfusion, and direct inflammatory effect on GI mucosa.
The prevalence of acute pancreatitis was $0.27 \%$ among hospitalized COVID-19 patients with no other identifiable etiology [30].

\section{Laboratory findings on COVID-19-associated GI and liver injury}

Figure 3 illustrates the most common laboratory tests specific for GI and liver infection with their possible clinical implications.

\section{General systemic and inflammatory markers (not organ- specific)}

COVID-19 patients showed high levels of C-reactive protein (CRP), lactate dehydrogenase (LDH), and $\alpha$ hydroxybutyrate dehydrogenase $(\mathrm{HBDH})$ as a result of inflammation-inducing GI or liver injury [31]. Interleukin-6 (IL-6) is a crucial cytokine contributing to the host defense by producing acute-phase proteins and proliferation of B-lymphocytes and neutrophils. In the liver, SARS-CoV-2 activates hepatic stellate cells and Kupffer cells to produce many inflammatory factors such as tumor necrosis factor- $\alpha$ (TNF- $\alpha$ ), interleukin (IL-6), and chemokines [19]. Moreover, COVID-19 patients with chronic liver disease (CLD) had a higher serum IL6 level than those without CLD [32].

\section{Laboratory findings specific for $\mathrm{Gl}$ infection}

A high proportion of serum CD19+ B cells, IgA, and low citrulline have been reported in COVID-19 patients presenting with diarrhea, indicating a direct viral cytopathic effect or intestinal ischemia inducing mucosal injury [33]. In contrast, increased serum CCL28 expression was associated with a good mucosal immune response [34]. Fecal calprotectin (FC) has evolved into a reliable biomarker allowing detection of intestinal inflammation in inflammatory bowel disease (IBD) and infectious colitis. High FC in COVID-19 patients indicates an acute GI inflammatory response and/or serves as a potential indicator of the progressive course in IBD patients [35].

Although SARS-CoV-2 induced pancreatic injury, elevated lipase levels exceeding three times the upper limit could be an alarm for GI injury rather than pancreatic injury. However, hyperlipidemia is not considered a marker of severe COVID-19 infection or a poor clinical outcome [36]. Acute hyperglycemia and transient type2-diabetes also indicate a pancreatic injury and are associated with poor prognosis.

\section{Laboratory findings specific for liver infection}

The available liver enzyme data varied widely due to a lack of a standard cut-off point and a consensus definition of severe cases. The prevalence of liver abnormalities has been classified into hepatocyte-type (aspartate aminotransferase [AST]/alanine aminotransferase 


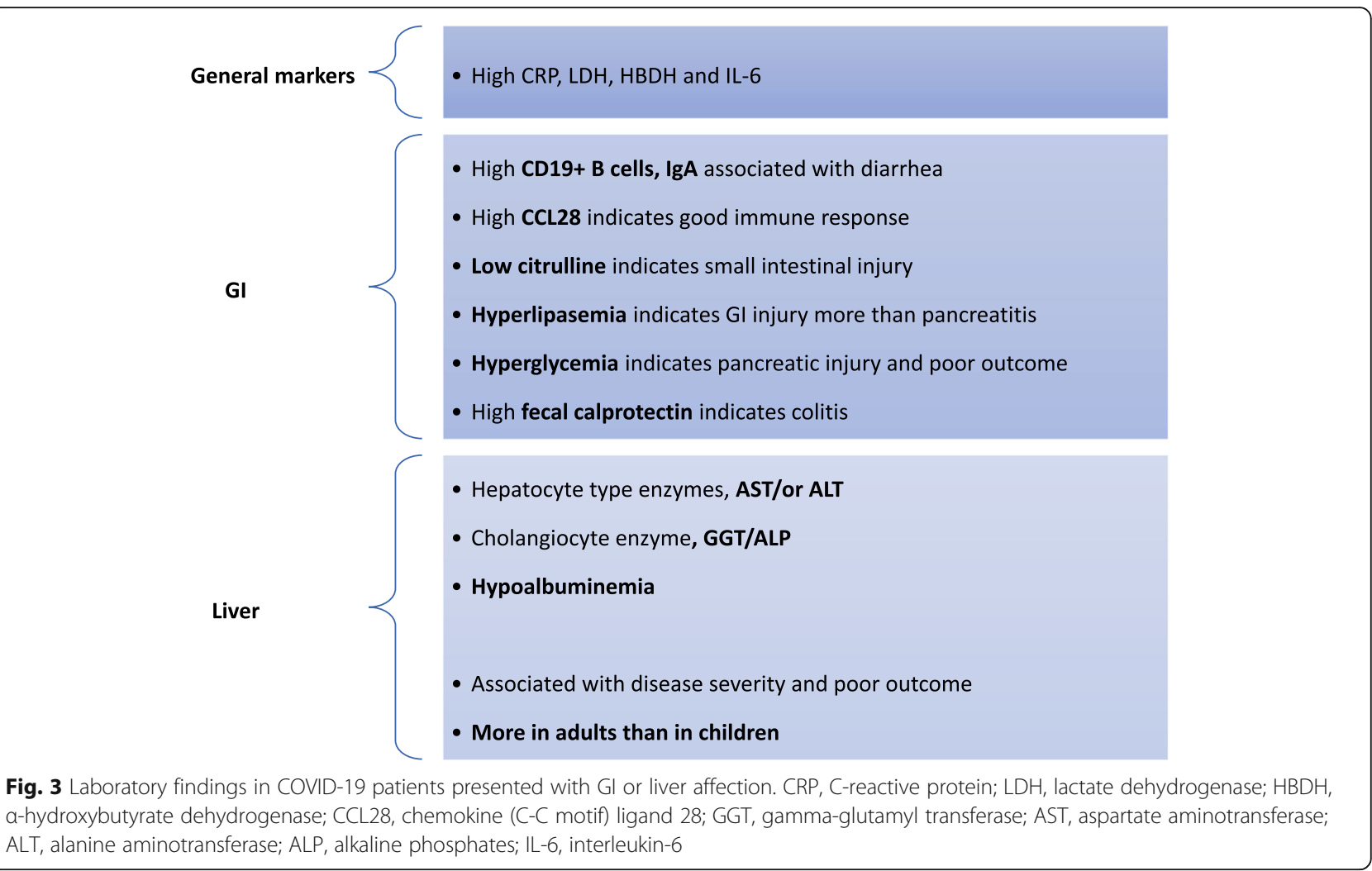

[ALT]) (20.75\%), cholangiocyte-type (gamma-glutamyl transferase [GGT]/alkaline phosphatase [ALP]) (29.25\%), and mixed types [37]. According to the frequency of elevated hepatocyte-type markers, ALT and AST were found to be elevated in $21.2-25 \%$ and $15.2-25 \%$ of patients, respectively. AST is typically located in the cytosol and mitochondria of hepatocytes, mainly in zone 3. Therefore, elevated serum AST could reflect direct cytopathic damage of hepatocytes or hypoxic changes. However, AST is not a specific marker for liver injury and has a broader organ distribution, indicating its involvement in multi-organ damage [38].

The prevalence of cholangiocyte-related enzymes showed increased levels of GGT (22.7\%) and total bilirubin (9\%), though serum ALP is controversial. Since GGT and ALP are expressed in sites other than the bile duct, their level could indicate multi-organ damage and cannot be classified solely as a specific bile duct marker. Furthermore, GGT has been identified as a surrogate marker for increased oxidative stress and chronic inflammation [39]. Therefore, elevated cholangiocyte markers are not specific for bile damage, as shown by rare pathological features of bile damage or cholestasis.

The synthetic liver function is altered by SARS-CoV-2 infection, resulting in hypoalbuminemia, an independent predictor of patient mortality. Albumin deficiency may be related to insufficient protein intake, serum protein exudation due to inflammation, diarrhea, or direct liver injury [40]. Furthermore, hepatic dysfunction badly impacts the coagulative and fibrinolytic pathways, platelet count, neutrophil counts with high neutrophil-tolymphocyte ratios, and serum ferritin levels [33].

\section{Radiological findings during the SARS-CoV-2 pandemic} Radiology plays a fundamental role in diagnosing COVID-19 patients based on chest findings. rRT-PCR may give initial false-negative results with a sensitivity of $83.3 \%$ for early COVID-19. In contrast, typical CT radiological findings demonstrated a sensitivity of nearly 97.2\% for diagnosing early COVID-19 and a low rate of missed COVID-19 diagnoses [41, 42]. However, chest CT should not be used exclusively for diagnosing COVID-19 infection, especially in asymptomatic patients [43]. Moreover, abdominal imaging becomes critical in COVID-19 patients who initially or exclusively present with GI symptoms. Abdominal imaging plays a role in determining the mechanism of SARS-CoV-2-induced injury, which may be thromboembolic or nonthromboembolic.

\section{Abdominal imaging findings in patients with SARS-CoV-2 infection}

Numerous radiological findings related to COVID-19 have been reported. The findings were separated into 
four groups to clarify the potential cause of injury (see Fig. 4).

Using contrast-enhanced computed tomography (CECT), enterocolitis of the abdomen was mainly observed in the right-sided colon (ascending colon and transverse colon) but was also involved in any bowel loop [44]. Many bowel ischemia cases in either the small or large bowel were detected by CECT. Occlusive ischemia resulted from thrombosis of the large or small mesenteric arteries, as determined by $\mathrm{CT}$ angiography or pathology, respectively. However, non-occlusive bowel ischemia with patent mesenteric arteries was attributed to hypoxia or low cardiac output. In CT angiography, the presence of isolated venous thrombosis in the mesenteric, portal vein, or inferior vena cava was associated with bowel wall edema without evidence of ischemic changes [45]. Pneumatosis intestinalis, a radiological sign suggestive of necrotizing enterocolitis, is another characteristic associated with bowel ischemia in COVID-19 patients. However, pneumatosis intestinalis might be discovered accidentally in the absence of clinical or radiological evidence of bowel ischemia. Epiploic appendagitis and perforation of the small and large bowel have been reported in some cases as direct sequelae of infection or secondary to ischemia [44].

Motility disorders have been identified in few COVID19 patients, with some exceptions; one case with paralytic ileus resolved after conservative treatment [46]. Another case involved a pediatric patient presenting with abdominal pain and ileocecal intussusception [47]. Motility disorder could be induced by an imbalance of the colon's autonomic innervation, a common feature of coronaviruses. However, further research is recommended to determine if these findings are linked to COVID-19 or concomitant.

Two studies reported the association of appendicitis and mesenteric lymphadenitis with SARS-CoV-2 infections. However, further ancillary studies on the resected specimen were recommended to confirm this hypothesis [8]. Similarly, a COVID-19 case has been identified in which a patient presented with a mild form of pancreatitis, absent of other causes [44].

\section{Hepatic imaging findings in patients with SARS-CoV-2 infection}

Hepatic injury was reported frequently in abdominal ultrasound (US) and CT in the form of hepatomegaly, periportal edema, pericholecystic fat stranding, and portal lymphadenopathy. One study showed a significantly lower liver to splenic CT attenuation ratio in COVID-19 patients than in the control group. Assessment of liver stiffness (LS) using combined US and elastography revealed a linear correlation between LS and biochemical markers for acute liver damage, indicating that elastography can be used as a reliable non-invasive indicator of hepatic injury in COVID-19 patients [48].

Hepatic steatosis appearing as a hepatic hypodensity in CT was higher in COVID-19 patients than in the control group. Thus, hepatic steatosis was suggested as a risk factor for SARS-CoV-2 infection [44]. However, it is unknown whether steatosis is a risk factor or a result of COVID-19.

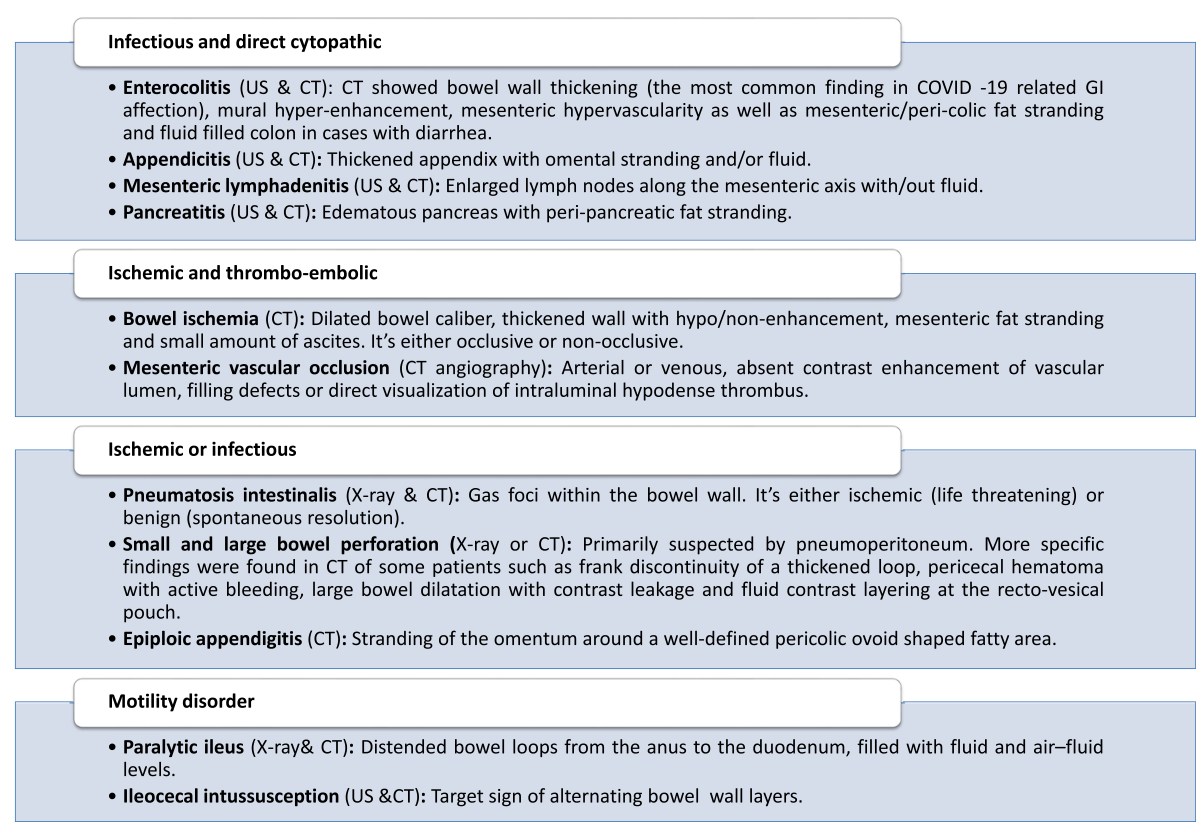

Fig. 4 Abdominal radiological findings of COVID-19-associated Gl symptoms. CT, computed tomography; US, ultrasound; Gl, gastrointestinal 
Biliary system manifestations were reported in COVID-19 patients in the form of bile stasis with subsequent gall bladder distention and sludge formation [44]. Furthermore, edema of the gall bladder wall, hepatic bed, and pericholecystic fat stranding were observed independently or as part of hepatic injury.

Finally, solid organ acute infarction was reported in two COVID-19 patients, involving the kidney, spleen, or liver [44].

\section{Histopathological findings of COVID-19-associated GI and liver injury}

The role of histopathology in the diagnosis of COVID19 aims to detect viral host receptors, assess pathological features, visualize viral particles, and understand disease mechanisms. Moreover, virus detection by immunohistochemistry (IHC) can be recognized directly by the pathologist, saving time and money to confirm a potential suspected case of COVID-19.

\section{Pathological findings of GI-related COVID-19}

The small intestine, primarily absorptive and crypt enterocytes but not goblet, Paneth, or enteroendocrine cells, expressed more ACE2 receptors than other GI sites [49]. Furthermore, histopathological analysis of 14 GI specimens obtained either post-mortem or by resection revealed ischemic changes in the form of mucosal necrosis or transmural hemorrhagic infarction [50]. The possible etiology of ischemia was thrombi in mucosal or mesenteric blood vessels in six cases, vasculitis and endothelial inflammation in four cases, and mixed thrombi and endotheliitis in two cases. Hobnail modifications of the endothelial cells with bizarre nuclear shapes have been also reported [51]. Inflammation was evident in seven cases: two of lymphoplasmacytic nature, two of acute nature, and three of undefined nature. Three cases of microscopic colitis were reported; however, there is insufficient evidence to determine whether these cases are SARS-CoV-2 related or incidental findings. There were seven attempts to detect SARS-CoV-2 viral particles in GI specimens. Positive viral particles were observed in the mucosa and the endothelial cells in five and two cases, respectively [51]. Moreover, Stah et al. detected intact viral particles in the bowel endothelium 8 weeks after initial infection and viral clearing in respiratory and blood specimens [52]. However, negative results were reported in six cases: two for the esophagus, two for the colon, one for the stomach, and one for the duodenum. The two reported appendicitis cases showed mucosal necrosis, non-caseating granulomas, and a foreign body reaction associated with severe mesenteric necrotizing lymphadenitis or ulcerophelgmonous [8].

\section{Pathological findings of liver-related COVID-19}

There has been a limited pathology role in diagnosing liver-associated COVID-19 abnormalities, with the majority of specimens obtained post-mortem [32, 53-55]. Histopathological characteristics varied, with most cases exhibiting a mixed pattern of injury. Histopathological changes included steatosis, either microvesicular and/or macrovesicular (61/95), inflammation with variable distribution including portal, sinusoidal, lobular, or panacinar (64/101), vascular abnormalities (54 cases), endotheliitis (3 cases), and lobular necrosis/apoptosis (15 cases). Other pathological findings reported in low frequency included Kupffer cell hyperplasia, giant cells transformation, lobular cholestasis, granuloma, and type II fibrinogen deposition. Moreover, bile duct damage was reported in only two cases. Numerous experiments used various techniques to visualize the viral particles, including electron microscopy (EM), polymerase chain reaction (PCR), or even $\mathrm{IHC}$, with positive findings encountered in 15/22 cases [54, 55]. Rather than viral particles, some authors interpreted the EM findings as clathrin-coated vesicles, which are involved in synaptic vesicle reconstitution, or multi-vesicular bodies, which are routinely discovered post-mortem. Several studies have conducted a C4d IHC test to assess immunological background, and only one case was positive (1/50) [5456].

The histopathological findings of steatosis, acute hepatitis, and positive viral tissue detection indicate a poor patient outcome. Histopathological observations were interpreted to gain a better understanding of the potential mechanism of injury (see Fig. 5).

\section{Management therapies in SARS-CoV-2-associated GI and liver diseases}

Treatment of COVID-19 associated GI or liver infection aims to clear the viral infection, relieve symptoms, and stabilize patients with previous GI or liver diseases. All therapies are critical for their anti-inflammatory properties and reduce viral entry, host receptor binding, and replication.

In addition to viral target therapies, symptomatic treatment is discussed, including oral or intravenous hydration and antiemetic medications. The anti-diarrheal agent loperamide can be used in patients without fever or bloody stools and after ruling out other infectious causes. Patients with non-variceal upper GI bleeding can be conservatively treated with PPIs and coagulation optimization without endoscopic intervention. However, PPIs are associated with hypochlorhydria, which increases the risk of SARS-CoV-2 entering the gut from the stomach, causing viral infection. Therefore, PPIs should be used at the lowest effective dose (once daily) [57]. Similarly, endoscopic evaluation for lower GI 


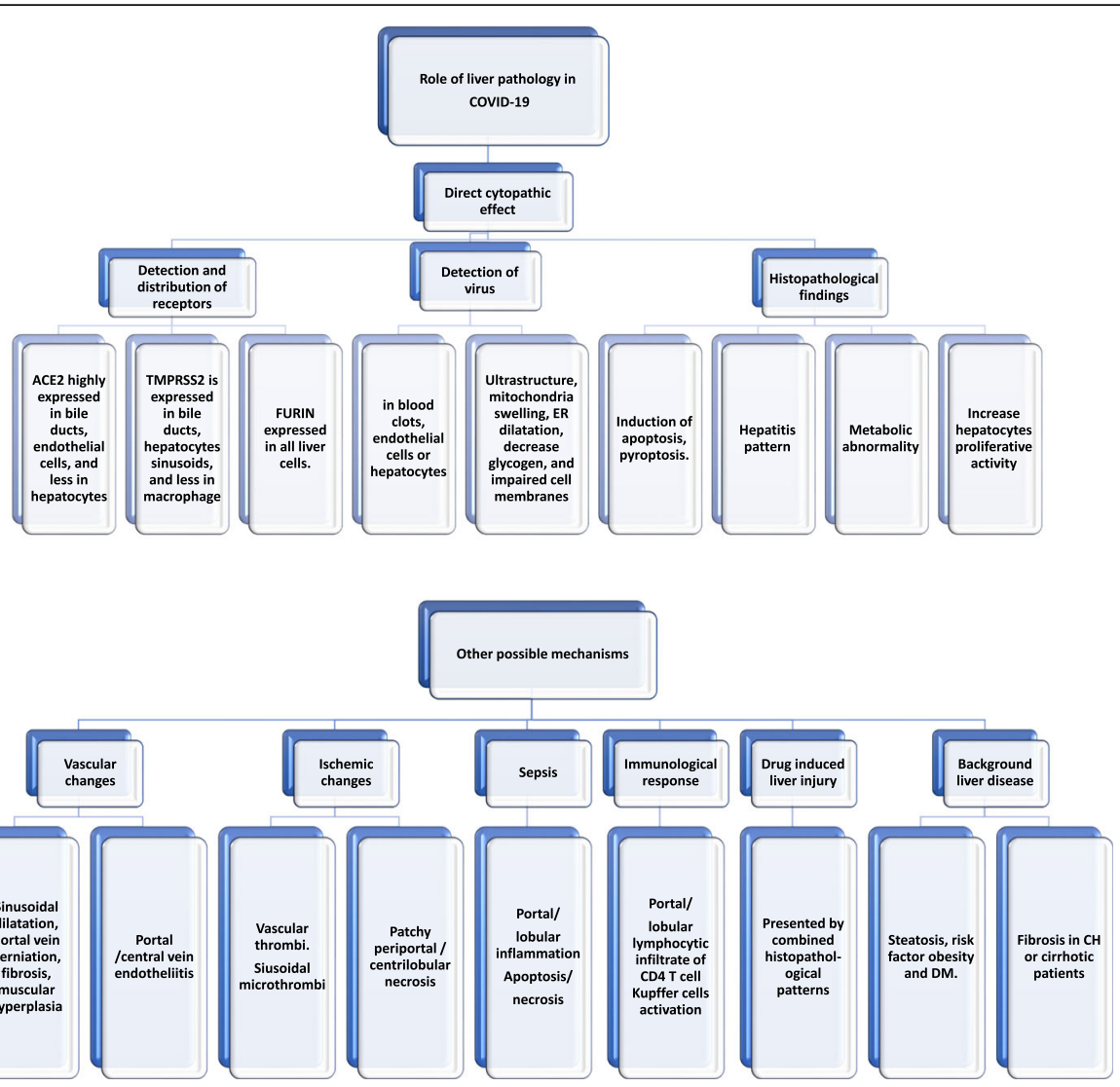

Fig. 5 The role of pathology in understanding SARS-CoV-2-induced liver injury mechanism. ACE2, angiotensin-converting enzyme-2; TMPRSS2, transmembrane protease, serine 2

bleeding might be initially postponed until acute disease resolution. For patients with severe COVID-19associated liver damage, hepatoprotective, antiinflammatory, and jaundice-reducing agents, as well as vitamin E, are recommended [58].

\section{Management of background $\mathrm{Gl}$ and liver diseases during the SARS-CoV-2 pandemic}

Many studies discussed the strategies for managing IBD patients during the SARS-CoV-2 pandemic in connection with several factors, mainly proper interpretation of the complaint, whether related to COVID-19 or acute flaring of the primary disease. For active IBD patients without SARS-CoV-2 infection, adding or escalating anti-inflammatory or biologic therapy for symptomatic improvement and remission induction may be involved. However, systemic glucocorticoids should be used at the lowest effective therapeutic dose [59]. On the other hand, the aim of therapy in patients with inflammatory bowel disease (IBD) infected with SARS-CoV-2 is to minimize immunosuppression during active viral infection to avoid viral complications (e.g., pneumonia). Two strategies are proposed for COVID-19 patients with IBD in remission: continue therapy indefinitely with budesonide, aminosalicylates, sulfasalazine, topical glucocorticoids, and antibiotics [59], or temporarily adjust medication until symptoms resolve, including systemic glucocorticoids and immunomodulators [60].

Immunosuppressive therapy reduction or discontinuation is not recommended for asymptomatic patients who have undergone liver transplantation and posttransplant treatment unless they are SARS-CoV-2 positive. Similarly, HCC-related treatments should be administered without any delay.

\section{Drug-induced GI and liver injury (DILI)}

Certain drugs are alleged to play a role in GI and liver injury. The possible mechanisms include reactive metabolites and oxidative stress, idiosyncratic through drugcytochrome P-450 interaction, or synergistic inflammatory response [61-63]. Table 1 summarizes the potential therapeutic agents, their mechanism of action, common side effects relating to the GI and liver, and possible drug-drug interactions (DDIs).

Hepatic patients with non-alcoholic fatty liver disease (NAFLD) infected with SARS-CoV-2 might be more 
susceptible to DILI [64]. Dexamethasone was found to decrease mortality rates among COVID-19 patients; however, it may lead to chronic hepatitis B virus (HBV) reactivation. Similarly, tocilizumab, an IL-6 blocker, increases HBV reactivation risk. Therefore, hepatitis B surface antigen ( $\mathrm{HBsAg}$ )-positive patients should also be treated with anti-viral medication for the duration of steroid therapy.

For patients with severe alcoholic or autoimmune hepatitis, caution must be taken when suggesting the initiation of steroids or other immunosuppressive therapy [65]. Regimens containing chloroquine or remdesivir were generally considered safe. Hydroxychloroquine should be treated for cardiac arrhythmias in patients receiving hepatitis $\mathrm{C}$ treatment [66].

\section{Demographic data of SARS-CoV-2-associated GI and liver infection \\ Geographical distribution of Gl symptoms}

The SARS-CoV-2 associated with GI manifestations was reported later in the COVID-19 pandemic. A potential reason is that the prevalence of GI symptoms is 2-3 times lower in China, the epicenter of the outbreak, than in western countries, primarily Europe and the USA; however, there was no statistically significant difference between the country-based studies [23]. Furthermore, an analysis of Chinese studies showed a constant low prevalence of diarrhea and vomiting before, during, and after April [67]. These observed differences could result from variability in SARS-CoV-2 host receptor gene expression, coagulation activity, and health care access amongst different socio-economic groups and ethnicities, all of which affect COVID-19 pathogenesis. Chinese populations have a lower risk of thrombo-embolic complications than other ethnic groups, which reduces the severity of COVID-19 [68]. However, geographic differences between countries remain unexplored.

\section{Age-related GI and liver symptoms}

COVID-19 patients with GI symptoms ranged in age from 1 day to 92 years, with a pooled mean age of 48.7 \pm 16.5 years [39]. The frequency of patients presenting with COVID-19-related GI symptoms did not show much variance, remaining at nearly $10 \%$ for all age groups [69]. Age was positively correlated with the severity of GI symptoms and mortality. Possible factors include low expression of ACE receptors, lower intensity of viral exposure, the protective effects of live vaccines, increased susceptibility to recurrent infections, and the difference in the adaptive, cellular immunity, and microbiota in children. In contrast to the age-related vascular and endothelial damage, prior coronavirus exposure and associated comorbidities negatively impact the disease course in the elderly [70].

\section{Gender differences of SARS-CoV-2-associated GI and liver symptoms}

According to a recent meta-analysis by Kaur et al., which included 6635 COVID-19 patients, COVID-19infected individuals were predominantly male. However, the manifestation of GI symptoms was significantly different between males and females. Self-reported GI symptom frequency during the COVID-19 course was significantly higher among women than men $(\mathrm{P}<0.001)$. Zouh et al. found a significantly higher proportion of female COVID-19 patients with GI symptoms associated with COVID-19 [71]. The exact mechanism is not elucidated; however, it could be hormonal modulation of the gustatory system. Notably, global data suggested male gender is a negative indicator of disease severity and mortality. Factors responsible for higher male mortality could include higher rates of smoking, respiratory tract infection, proinflammatory cytokines, and the immunosuppressive effect of testosterone. However, Agrawal et al. suggested that the estrogen-enhancing effect and the localization of immune response genes on $\mathrm{X}$ chromosome may protect females [72].

\section{The prognosis of SARS-CoV-2-induced GI and liver infection} There was no consensus regarding the impact of GI symptoms on the COVID-19 course. Studies reported no significant difference in the prevalence of diarrhea, nausea, or vomiting between severe and non-severe patients [22]. Another study reported patients presenting with COVID-19-related GI symptoms to have a low mortality rate compared to those without GI symptoms [73]. In contrast, other studies reported a poor outcome for COVID-19 patients who presented with GI symptoms, especially abdominal pain $[69,74]$. The low prognostic impact of GI symptoms could be related to the marked electrolyte imbalance, gut dysbiosis, ischemicreperfusion injury, and associated neurological manifestations.

Notably, there was a consensus of the poor prognostic impact of elevated liver enzymes on COVID-19 patients [69]. In extreme COVID-19 patients, hypoalbuminemia, high GGT, aminotransferase (AST > ALT), and bilirubin rather than serum ALP levels were observed [39].

\section{The impact of background GI and liver diseases on the outcome of SARS-CoV-2 infection}

There was no correlation between autoimmune GI diseases and the increased risk of SARS-CoV-2 infection. Patients with IBD are not at greater risk and can maintain remission with maintenance therapy [59]. Similarly, celiac disease patients showed no increased risk for 
Table 1 Potential GI and liver adverse effects and drug interaction profile of COVID-19 investigational drugs

\begin{tabular}{|c|c|c|c|c|}
\hline & Mechanism of action & Gl affection & Liver affection & Major drug-drug interactions \\
\hline $\begin{array}{l}\text { Chloroquine/ } \\
\text { hydroxychloroquine } \\
\text { [80] }\end{array}$ & $\begin{array}{l}\text { Interferences with terminal } \\
\text { glycosylation of ACE2 } \\
\text { receptor } \\
\text { Blocks viral entry by } \\
\text { increasing endosomal pH } \\
\text { and inhibiting viral fusion to } \\
\text { the cell membrane }\end{array}$ & $\begin{array}{l}\text { Nausea, vomiting, weight loss, } \\
\text { abdominal pain }\end{array}$ & $\begin{array}{l}\text { Rare elevations in } \\
\text { aminotransferases. } \\
\text { Most reactions are } \\
\text { Idiosyncrasy or } \\
\text { oxidative stress. }\end{array}$ & $\begin{array}{l}\text { A moderate inhibitor of CYP2D6 and } \\
\text { P-gp } \\
\text { Significant particularly with anti- } \\
\text { rejection immunosuppressants. } \\
\text { Weak interaction with tenofovir/ } \\
\text { entecavir } \\
\text { Hydroxychloroquine given to a } \\
\text { patient taking hepatitis c treatment } \\
\text { should monitor for cardiac } \\
\text { arrhythmia }\end{array}$ \\
\hline
\end{tabular}

Ivermectin [81] mediated nuclear import, which reduces the replication of the virus and so the viral load

Nitazoxanide [82] Antiparasitic drug has broadspectrum anti-viral activity

Atazanavir [83] Protease inhibitors

Favipiravir [84]

Interferon beta [85]

Lopinavir/ritonavir [86]

Remdesivir [87]

Ribavirin [88]

Anakinra [89]

Baricitinib [90]
RNA-dependent RNA polymerase inhibitor
RNA-dependent RNA polymerase inhibitor

Cytokines with anti-viral and immunomodulatory effects.

HIV protease inhibitor/ CYP450inhibitor abdominal pain

Nausea/vomiting (5-15\%), diarrhea (5\%)

Nausea, vomiting

Nausea/vomiting (5-10\%), abdominal pain (1-10\%), diarrhea (10-30\%), dysgeusia $(<2 \%)$, increased serum amylase/lipase.

Nausea, vomiting

Inhibit capping of viral messenger RNA, and the viral RNA-dependent polymerase

IL-1R inhibitor

JAK1 and JAK2 inhibitor Inhibit viral endocytosis

Reduction of IL-8, monocyte chemo-attractant protein-1,

Nausea diarrhea

Bowel perforation, nausea, vomiting

Nausea, peptic ulcers patients with
Abdominal pain (8\%), diarrhea Increased ALT: <1\% $(2 \%)$, nausea $(3 \%)$, vomiting $(1 \%)$

Diarrhea, nausea, vomiting,

Very few reports on elevated liver enzymes or Jaundice

Avoid concomitant use of ivermectin with other drugs that enhance GABA activity

Rapidly hydrolyzed to tizoxanide. which is highly protein-bound (>99\%), so caution when giving with other highly protein-bound drugs with narrow therapeutic indices.

Inhibitor of CYP3A4 and CYP2C9 PPI decreases its concentrations. Tenofovir and efavirenz should not hyperbilirubinemia with overt jaundice Elevation of hepatic enzymes especially in underlying $\mathrm{HBV}$ or $\mathrm{HCV}$ co-infection

Rare abdominal pain, nausea,
Liver enzyme abnormalities

Elevated liver enzymes

Hepatotoxicity ranges from mild elevations in aminotransferases to acute liver failure. Recovery takes $1-2$ mo.

Might include drugcytochrome P-450 interaction

Deranged liver enzymes Hepatotoxicity reported; frequency is not yet known.

Hepatotoxicity

NA

Hepatobiliary disorders: No effect on CYP450.

Elevated transaminases, noninfectious hepatitis

Inhibitor for: CYP2C8 and aldehyde oxidase

DDI potential not fully evaluated. Possible inhibitor of CYP enzymes

Substrate for: CYP3A4, CYP2D6, P-gp Inducer for: CYP1A2, CYP2B6, CYP2C8, CYP2C9, CYP2C19, UGT1A1

Inhibitor for: CYP3A4 Increased levels of Immunosuppressive drugs (calcineurin and mTOR inhibitors). Moderate interaction risk with tenofovir with renal functions monitoring.

Lopinavir/ ritonavir increase concentrations of hepatitis $C$ treatment.

NA

Hepatitis $\mathrm{B}$ reactivation

Partially metabolized by CYP3A4 and a substrate for OAT3 and P-gp OAT3 inhibitors cause a significant effect on baricitinib exposure

Aspirin can increase the risk of bleeding when used with it 
Table 1 Potential Gl and liver adverse effects and drug interaction profile of COVID-19 investigational drugs (Continued)

\begin{tabular}{|c|c|c|c|c|}
\hline & Mechanism of action & Gl affection & Liver affection & Major drug-drug interactions \\
\hline & $\begin{array}{l}\text { and Th1 chemokine IFN- } \gamma^{-} \\
\text {inducible protein-10 }\end{array}$ & & & \\
\hline Ruxolitinib [91] & Selective JAK inhibitors & NA & $\begin{array}{l}\text { Increased ALT } \\
\text { Increased AST }\end{array}$ & $\begin{array}{l}\text { Metabolized by CYP3A4 and CYP2C9. } \\
\text { So, it is liable to DDIs with inhibitors } \\
\text { or inducers of these enzymes. } \\
\text { Ruxolitinib may inhibit BCRP and P- } \\
\text { gp, and caution is indicated with co- } \\
\text { administering with substrates of } \\
\text { these transporters with narrow thera- } \\
\text { peutic indices. }\end{array}$ \\
\hline Sarilumab [92] & IL-6R inhibitor & $\begin{array}{l}\text { Few cases of gastrointestinal } \\
\text { perforation }\end{array}$ & Increased ALT & No effect on CYP450 \\
\hline Tocilizumab [93] & $\begin{array}{l}\text { IL-6R inhibitor (Curbs } \\
\text { cytokine release syndrome) }\end{array}$ & $\begin{array}{l}\text { Bowel perforation, pancreatitis, } \\
\text { abdominal pain }\end{array}$ & $\begin{array}{l}\text { Elevated liver enzymes, } \\
\text { Reactivation of chronic } \\
\text { hepatitis B }\end{array}$ & No effect on CYP450 \\
\hline
\end{tabular}

$A C E$ angiotensin-converting enzyme, $A L T$ alanine aminotransferase, $A S T$ aspartate aminotransferase, $B C R P$ breast cancer resistance protein, $C O V I D-19$ coronavirus disease-19, CYP cytochrome P450, DDI drug-drug interaction, GABA $\gamma$-aminobutyric acid, GI gastrointestinal, HIV human immunodeficiency virus, IFN interferon, IL interleukin, IMP a/ $\beta$-mediated nuclear import, JAK Janus kinase, OAT organic anion transporter, P-gp P-glycoprotein, PPI proton pump inhibitor, Th t-helper, TOR target of rapamycin

SARS-CoV-2 infection or primary disease complications [75].

In CLD patients, SARS-CoV-2 infection stimulates inflammatory mediators and decreases ACE2 expression, aggravating liver cirrhosis [76]. Furthermore, NAFLD patients infected with SARS-CoV-2 might be more vulnerable to DILI, a cytokine storm, and ischemic damage to the liver [77]. Similarly, HBV patients coinfected with SARS-CoV-2 could experience HBV reactivation following therapy [78]. Therefore, the liver function in patients with CLD should be monitored regularly throughout the SARS-CoV-2 infection.

\section{Discussion}

The digestive tract may serve as a possible route of SARS-CoV-2 transmission to the liver, appendix, and brain. The virus reaches the gut through fecal transmission, saliva, or vomiting. The persistence of viral indicators in the stool may be used as a surrogate monitor for recurrent infection [27]. A GI and liver injury mechanism is a multi-hit hypothesis requiring interaction between genetics, multiple organ cross-talk, and vascular and inflammatory response [4]. Demographic studies have proposed a low prevalence of COVID-19associated GI symptoms in China compared to other countries; however, there is no consensus on gender or age as predicting factors [27]. The high-risk factors include the male gender, old age, anorexia, abdominal pain, liver enzyme abnormalities, and the histopathological findings of steatosis, acute hepatitis, and positive viral tissue detection. Surprisingly, SARS-CoV-2 infection may worsen the background liver disease, with low or no impact on pre-existing GI diseases [76].

Typical GI symptoms experienced by some COVID-19 patients included diarrhea, nausea, vomiting, and abdominal pain, which may even necessitate surgical interventions [20, 29]. Therefore, all patients with GI symptoms should be eligible for SARS-CoV-2 testing as these symptoms may precede the respiratory symptoms or be the only symptoms [23]. In contrast, liver injury is observed during laboratory investigation or post-mortem pathological studies. Liver function tests should be monitored even in the absence of hepatic symptoms. Abnormalities in liver enzymes are reported in similar frequencies despite the presence of pre-existing liver disease [79], and unexplained elevation of ALT/AST, an increase of bilirubin, and reduced albumin levels in a clinically suspect patient may indicate COVID-19 infection. The mechanism of GI injury is multifactorial, with infection and ischemic-thromboembolic alteration playing a significant role. A subsequent intestinal malabsorption, imbalance in intestinal secretions, intestinal dysbiosis, and activation of the enteric nervous system exacerbate the GI infection. Even more, the mucosal injury could mediate viral spread throughout the bowel wall [26].

Similarly, the mechanism of liver injury is multifactorial, confirmed by mixed histopathological findings, laboratory results, and radiological investigations. The direct viral cytopathic effect has been explained by broad hepatic SARS-CoV-2 host receptor distributions [15]. Vascular alterations result from increased blood flow, endothelial injury, endotheliitis, thrombosis, and concomitant thrombotic changes in the pulmonary vessels [54]. However, Lagana et al. reported that liver vascular abnormalities do not correlate with pulmonary dysfunction [55]. The lack of pathological features of ischemia did not explain the elevated serum aminotransferase levels in COVID-19 patients but rather raises the possibility of another mechanism other than hypoxic- 
ischemic injury. Similarly, the pathological findings of sepsis are reported only in four cases [55]. The immunological and cytokine storm mechanism contributes significantly to liver damage by releasing inflammatory mediators and activating different immune cells [19]. The expression of C4d was focally positive in only one case $[54,55]$. Therefore, the immunological response is more cellular than humoral. DILI is a possible mechanism, though it is still a diagnosis of exclusion. The presence of steatosis and mixed histopathological findings supports drug-induced damage [55]. However, Wang et al. found no significant differences in drug adherence between patients with normal and abnormal liver enzymes [22]. Moreover, hepatotoxicity usually occurs after long-term antiviral therapy. Finally, most histopathological changes in the liver were limited or related to underlying liver diseases [53].

\section{Suggestions for future research}

COVID-19 associated with GI and liver injury is an emerging research era with many questions with no definite answers. The mechanism by which some individuals experience GI symptoms rather than respiratory symptoms is not well elucidated. The route of GI transmission and the virus's ability to survive the extremes of $\mathrm{GI} \mathrm{pH}$ require further studies. The reliable role of elevated liver enzymes during SARS-CoV-2 infection must also be investigated because liver damage is usually an incidental finding in the routine laboratory or pathological investigation. Improving the histopathological tools in detecting viral particles could aid in elucidating disease mechanisms. More studies are recommended to identify the essential structural proteins of SARS-CoV-2 that promote tissue invasion and replication. Accordingly, improved selective and targeted therapeutic agents could be developed.

\section{Conclusions}

SARS-CoV-2 infection resulted in GI and liver disease through multi-hit complex mechanisms. GI manifestations are normal in COVID-19 patients, and particular attention should be given to high-risk patients, including those who are older, male, and have abdominal pain, elevated liver enzymes, or background liver disease.

\footnotetext{
Abbreviations

SARS-CoV-2: Severe acute respiratory syndrome coronavirus 2;

Gl: Gastrointestinal; COVID-19: Novel 2019 coronavirus disease;

ACE2: Angiotensin-converting enzyme 2; TMPRSS2: Transmembrane protease serine 2; ENS: Enteric nervous system; EGCs: Enteric glial cells; TLRs: Toll-like receptors; CatB/L: Cathepsin B and L; SIRS: Systemic inflammatory response syndrome; PPIs: Proton pump inhibitors; CRP: C-reactive protein; LDH: Lactate dehydrogenase; HBDH: a-hydroxybutyrate dehydrogenase; IL-6: Interleukin-6; TNF-a: Tumor necrosis factor-a; CLD: Chronic liver disease; FC: Fecal calprotectin; IBD: Inflammatory bowel disease; AST: Aspartate aminotransferase; ALT: Alanine aminotransferase; GGT: Gamma-glutamyl transferase; ALP: Alkaline phosphatase; CECT: Contrast-enhanced computed
}

tomography; US: Ultrasound; LS: Liver stiffness; EM: Electron microscopy; PCR: Polymerase chain reaction; IHC: Immunohistochemistry; DDI: Drug-drug interactions; DILI: Drug induced liver injury; HBV: Hepatitis B virus; HBsAg: Hepatitis B surface antigen; NAFLD: Non-alcoholic fatty liver disease

\section{Acknowledgements \\ Not applicable.}

\section{Authors' contributions}

All authors of this paper have participated in its drafting and approved the final version submitted. DS wrote the pathological part, EA wrote the GI and hepatology part, EK wrote the radiological part, HA and SA wrote the biochemical and mechanism of disease, HM wrote the mode of spread and mechanism of disease, IM made the online search and wrote the epidemiological part, NA contributed to paper editing, and ES wrote the pharmacological part. All authors acquired and interpreted the collected data. DS, AM, HE, and ES revised and edited the final version.

Funding

Not applicable.

Availability of data and materials

Available from the corresponding author on reasonable request.

\section{Declarations}

Ethics approval and consent to participate

Not applicable.

\section{Consent for publication}

Not applicable.

\section{Competing interests}

The authors have no conflicts of interest to declare.

\section{Author details}

${ }^{1}$ Pathology Department, National Liver Institute, Menofia University, Shibin El Kom 32511, Egypt. ${ }^{2}$ Hepatology and Gastroenterology Department, National Liver Institute, Menofia University, Shibin El Kom, Egypt. ${ }^{3}$ Radiology Department, Faculty of Medicine, Menofia University, Shibin El Kom, Egypt. ${ }^{4}$ Clinical Pathology Department, National Liver Institute, Menofia University, Shibin El Kom, Egypt. ${ }^{5}$ Microbiology Department, Faculty of Medicine, Menofia University, Shibin El Kom, Egypt. ${ }^{6}$ Epidemiology and Preventive Medicine Department, Menofia University, Shibin El Kom, Egypt. ${ }^{7}$ Clinical Biochemistry, and Molecular Diagnostics Department, National Liver Institute, Menofia University, Shibin El Kom, Egypt. ${ }^{8}$ Ohio State College of Medicine, Columbus, OH, USA. ${ }^{9}$ Biochemistry Department, Faculty of Science, Cairo University, Giza, Egypt. ${ }^{10}$ Clinical Pharmacology Department, Faculty of Medicine, Menofia University, Shibin El Kom, Egypt.

Received: 24 February 2021 Accepted: 11 June 2021

Published online: 31 July 2021

\section{References}

1. Li Q, Guan X, Wu P, Wang X, Zhou L, Tong Y, Ren R, Leung KSM, Lau EHY, Wong JY, Xing X, Xiang N, Wu Y, Li C, Chen Q, Li D, Liu T, Zhao J, Liu M, Tu W, Chen C, Jin L, Yang R, Wang Q, Zhou S, Wang R, Liu H, Luo Y, Liu Y, Shao G, Li H, Tao Z, Yang Y, Deng Z, Liu B, Ma Z, Zhang Y, Shi G, Lam TTY, Wu JT, Gao GF, Cowling BJ, Yang B, Leung GM, Feng Z (2020) Early transmission din Wuhan, China, of novel coronavirus-infected pneumonia. N Engl J Med 382(13):1199-1207. https://doi.org/10.1056/NEJMoa2001316

2. Holshue ML, DeBolt C, Lindquist S, Lofy KH, Wiesman J, Bruce H, Spitters C, Ericson K, Wilkerson S, Tural A, Diaz G, Cohn A, Fox L, Patel A, Gerber SI, Kim L, Tong S, Lu X, Lindstrom S, Pallansch MA, Weldon WC, Biggs HM, Uyeki TM, Pillai SK, Washington State -nCo VCIT (2020) First case of 2019 novel coronavirus in the United States. N Engl J Med 382(10):929-936. https://doi. org/10.1056/NEJMoa2001191

3. Zhong P, Xu J, Yang D, Shen Y, Wang L, Feng Y, Du C, Song Y, Wu C, Hu X, Sun $Y$ (2020) COVID-19-associated gastrointestinal and liver injury: clinical features and potential mechanisms. Signal Transduction and Targeted Therapy 5(1):256. https://doi.org/10.1038/s41392-020-00373-7 
4. Pamplona J, Solano R, Soler C, Sabat M (2020) Epidemiological approximation of the enteric manifestation and possible fecal-oral transmission in COVID-19: a preliminary systematic review. Eur J Gastroenterol Hepatol Publish Ahead of Print. https://doi.org/10.1097/MEG. 0000000000001934

5. Li Y, Ren B, Peng X, Hu T, Li J, Gong T, Tang B, Xu X, Zhou X (2020) Saliva is a non-negligible factor in the spread of COVID-19. Mol Oral Microbiol 35(4): 141-145. https://doi.org/10.1111/omi.12289

6. Jones DL, Baluja MQ, Graham DW, Corbishley A, McDonald JE, Malham SK, Hillary LS, Connor TR, Gaze WH, Moura IB, Wilcox MH, Farkas K (2020) Shedding of SARS-CoV-2 in feces and urine and its potential role in personto-person transmission and the environment-based spread of COVID-19. Sci Total Environ 749:141364 https://doi.org/10.1016/j.scitotenv.2020.141364

7. Portincasa P, Krawczyk M, Machill A, Lammert F, Di Ciaula A (2020) Hepatic consequences of COVID-19 infection. Lapping or biting? Eur J Intern Med 77:18-24. https://doi.org/10.1016/j.ejim.2020.05.035

8. Ahmad S, Ahmed RN, Jani P, Ullah M, Aboulgheit H (2020) SARS-CoV-2 isolation from an appendix. J Surg Case Rep 2020(8):rjaa245. https://doi. org/10.1093/jscr/rjaa245

9. Groß R, Conzelmann C, Müller JA, Stenger S, Steinhart K, Kirchhoff F, Münch J (2020) Detection of SARS-CoV-2 in human breastmilk. Lancet 395(10239): 1757-1758. https://doi.org/10.1016/S0140-6736(20)31181-8

10. Cho HJ, Koo JW, Roh SK, Kim YK, Suh JS, Moon JH, Sohn SK, Baek DW (2020) COVID-19 transmission and blood transfusion: a case report. Journal of Infection and Public Health 13(11):1678-1679 https://doi.org/10.1016/j.jiph.2 020.05.001

11. Chen L, Marishta A, Ellison CE, Verzi MP (2021) Identification of transcription factors regulating SARS-CoV-2 entry genes in the intestine. Cell Mol Gastroenterol Hepatol 11(1):181-184. https://doi.org/10.1016/j.jcmgh.2020. 08.005

12. DosSantos MF, Devalle S, Aran V, Capra D, Roque NR, Coelho-Aguiar JM, TCLdSe S, Subilhaga JG, Pereira CM, D'Andrea Meira I, Niemeyer Soares Filho P, Moura-Neto V (2020) Neuromechanisms of SARS-CoV-2: a review. Front Neuroanat 14:37. https://doi.org/10.3389/fnana.2020.00037

13. Fändriks $L$ (2009) The angiotensin II type 2 receptor and the gastrointestinal tract. J Renin-Angiotensin-Aldosterone Syst 11(1):43-48. https://doi.org/10.11 77/1470320309347788

14. Garg M, Angus PW, Burrell LM, Herath C, Gibson PR, Lubel JS (2012) Review article: the pathophysiological roles of the renin-angiotensin system in the gastrointestinal tract. Aliment Pharmacol Ther 35(4):414-428. https://doi. org/10.1111/j.1365-2036.2011.04971.x

15. Davidson Anne M, Wysocki J, Batlle D (2020) Interaction of SARS-CoV-2 and other coronavirus with ACE (angiotensin-converting enzyme)-2 as their main receptor. Hypertension 76(5):1339-1349. https://doi.org/10.1161/ HYPERTENSIONAHA.120.15256

16. Ahlawat S, Asha SKK (2020) Immunological co-ordination between gut and lungs in SARS-CoV-2 infection. Virus Res 286:198103-198103. https://doi. org/10.1016/j.virusres.2020.198103

17. Panchal P, Budree S, Scheeler A, Medina G, Seng M, Wong WF, Eliott R, Mitchell T, Kassam Z, Allegretti JR, Osman M (2018) Scaling safe access to fecal microbiota transplantation: past, present, and future. Current Gastroenterology Reports 20(4):14. https://doi.org/10.1007/s11894-018-0619-8

18. Price $E$ (2020) Could the severity of COVID-19 be increased by low gastric acidity? Crit Care 24(1):456. https://doi.org/10.1186/s13054-020-03182-0

19. Castelli V, Cimini A, Ferri C (2020) Cytokine storm in COVID-19: "when you come out of the storm, you won't be the same person who walked in". Front Immunol 11:2132-2132. https://doi.org/10.3389/fimmu.2020.02132

20. Docherty AB, Harrison EM, Green CA, Hardwick HE, Pius R, Norman L, Holden KA, Read JM, Dondelinger F, Carson G, Merson L, Lee J, Plotkin D, Sigfrid L, Halpin S, Jackson C, Gamble C, Horby PW, Nguyen-Van-Tam JS, Ho A, Russell CD, Dunning J, Openshaw PJ, Baillie JK, Semple MG, investigators IC (2020) Features of 20133 UK patients in hospital with covid-19 using the ISARIC WHO Clinical Characterisation Protocol: prospective observational cohort study. BMJ 369:m1985-m1985. doi:https://doi.org/10.1136/bmj.m1985

21. Han C, Duan C, Zhang S, Spiegel B, Shi H, Wang W, Zhang L, Lin R, Liu J, Ding Z, Hou X (2020) Digestive symptoms in COVID-19 patients with mild disease severity: clinical presentation, stool viral RNA testing, and outcomes. Am J Gastroenterol 115(6):916-923. https://doi.org/10.14309/ajg. 0000000000000664

22. Wang H, Qiu P, Liu J, Wang F, Zhao Q (2020) The liver injury and gastrointestinal symptoms in patients with coronavirus disease 19: a systematic review and meta-analysis. Clin Res Hepatol Gastroenterol 44(5): 653-661. https://doi.org/10.1016/j.clinre.2020.04.012

23. Sultan S, Altayar O, Siddique SM, Davitkov P, Feuerstein JD, Lim JK, FalckYtter Y, El-Serag HB, AGAlEa (2020) AGA Institute rapid review of the gastrointestinal and liver manifestations of COVID-19, meta-analysis of international data, and recommendations for the consultative management of patients with COVID-19. Gastroenterology 159(1):320-334.e327. https:// doi.org/10.1053/j.gastro.2020.05.001

24. Freedberg DE, Conigliaro J, Wang TC, Tracey KJ, Callahan MV, Abrams JA, Famotidine Research G (2020) Famotidine use is associated with improved clinical outcomes in hospitalized COVID-19 patients: a propensity score matched retrospective cohort study. Gastroenterology 159(3):1129-1131. e1123. https://doi.org/10.1053/j.gastro.2020.05.053

25. Hunt RH, East JE, Lanas A, Malfertheiner P, Satsangi J, Scarpignato C, Webb GJ (2020) COVID-19 and gastrointestinal disease: implications for the gastroenterologist. Dig Dis. https://doi.org/10.1159/000512152

26. Luo S, Zhang X, Xu H (2020) Don't overlook digestive symptoms in patients with 2019 novel coronavirus disease (COVID-19). Clin Gastroenterol Hepatol 18(7):1636-1637. https://doi.org/10.1016/j.cgh.2020.03.043

27. Cheung KS, Hung IFN, Chan PPY, Lung KC, Tso E, Liu R, Ng YY, Chu MY, Chung TWH, Tam AR, Yip CCY, Leung K-H, Fung AY-F, Zhang RR, Lin Y, Cheng HM, Zhang AJX, To KKW, Chan K-H, Yuen K-Y, Leung WK (2020) Gastrointestinal manifestations of SARS-CoV-2 infection and virus load in fecal samples from a Hong Kong cohort: systematic review and metaanalysis. Gastroenterology 159(1):81-95. https://doi.org/10.1053/j.gastro.2020. 03.065

28. Tian Y, Rong L, Nian W, He Y (2020) Review article: gastrointestinal features in COVID-19 and the possibility of faecal transmission. Aliment Pharmacol Ther 51(9):843-851. https://doi.org/10.1111/apt.15731

29. Chan KH, Lim SL, Damati A, Maruboyina SP, Bondili L, Abu Hanoud A, Slim J (2020) Coronavirus disease 2019 (COVID-19) and ischemic colitis: an underrecognized complication. Am J Emerg Med 38(12):2758.e2751-2758.e2754. https://doi.org/10.1016/j.ajem.2020.05.072

30. Inamdar S, Benias PC, Liu Y, Sejpal DV, Satapathy SK, Trindade AJ (2020) Prevalence, risk factors, and outcomes of hospitalized patients with coronavirus disease 2019 presenting as acute pancreatitis. Gastroenterology 159(6):2226-2228.e2222 https://doi.org/10.1053/j.gastro.2020.08.044

31. Zhang H, Liao Y-S, Gong J, Liu J, Xia X, Zhang H (2020) Clinical characteristics of coronavirus disease (COVID-19) patients with gastrointestinal symptoms: a report of 164 cases. Dig Liver Dis 52(10):10761079. https://doi.org/10.1016/j.dld.2020.04.034

32. Xu Z, Shi L, Wang Y, Zhang J, Huang L, Zhang C, Liu S, Zhao P, Liu H, Zhu L, Tai Y, Bai C, Gao T, Song J, Xia P, Dong J, Zhao J, Wang F-S (2020) Pathological findings of COVID-19 associated with acute respiratory distress syndrome. Lancet Respir Med 8(4):420-422. https://doi.org/10.1016/S2213-2 600(20)30076-X

33. Zhang L, Han C, Zhang S, Duan C, Shang H, Bai T, Hou X (2020) Diarrhea and altered inflammatory cytokine pattern in severe coronavirus disease 2019: impact on disease course and in-hospital mortality. Journal of Gastroenterology and Hepatology n/a (n/a) 36(2):421-429. https://doi.org/1 $0.1111 /$ jgh.15166

34. Yan $Y$, Jiang $X$, Wang $X$, Liu B, Ding $H$, Jiang $M$, Yang Z, Dai $Y$, Ding D, Yu H, Zhang S, Liu J, Sha M, Lui C, Qiu Y, Lu H, Hu Q (2021) CCL28 mucosal expression in SARS-CoV-2-infected patients with diarrhea in relation to disease severity. J Infect 82(1):e19-e21. https://doi.org/10.1016/j.jinf.2020.08.042

35. Effenberger M, Grabherr F, Mayr L, Schwaerzler J, Nairz M, Seifert M, Hilbe R, Seiwald S, Scholl-Buergi S, Fritsche G, Bellmann-Weiler R, Weiss G, Müller T, Adolph TE, Tilg H (2020) Faecal calprotectin indicates intestinal inflammation in COVID-19. Gut 69(8):1543-1544. https://doi.org/10.1136/ gutjnl-2020-321388

36. Aghemo A, Piovani D, Parigi TL, Brunetta E, Pugliese N, Vespa E, Omodei PD, Preatoni P, Lleo A, Repici A, Voza A, Cecconi M, Malesci A, Bonovas S, Danese S, Humanitas C-TF (2020) COVID-19 digestive system involvement and clinical outcomes in a large academic hospital in Milan, Italy. Clin Gastroenterol Hepatol 18 (10):2366-2368.e2363. 18(10):2366-2368.e3. https:// doi.org/10.1016/j.cgh.2020.05.011

37. Cai Q, Huang D, Yu H, Zhu Z, Xia Z, Su Y, Li Z, Zhou G, Gou J, Qu J, Sun Y, Liu Y, He Q, Chen J, Liu L, Xu L (2020) COVID-19: abnormal liver function tests. J Hepatol 73(3):566-574. https://doi.org/10.1016/j.jhep.2020.04.006

38. Ferm S, Fisher C, Pakala T, Tong M, Shah D, Schwarzbaum D, Cooley V, Hussain S, Kim SH (2020) Analysis of gastrointestinal and hepatic 
manifestations of SARS-CoV-2 infection in 892 patients in Queens, NY. Clin Gastroenterol Hepatol 18(10):2378-2379.e2371. https://doi.org/10.1016/j. cgh.2020.05.049

39. Kumar-M P, Mishra S, Jha DK, Shukla J, Choudhury A, Mohindra R, Mandavdhare HS, Dutta U, Sharma V (2020) Coronavirus disease (COVID-19) and the liver: a comprehensive systematic review and meta-analysis. Hepatol Int 14(5):711-722. https://doi.org/10.1007/s12072-020-10071-9

40. Huang W, Li C, Wang Z, Wang H, Zhou N, Jiang J, Ni L, Zhang XA, Wang DW (2020) Decreased serum albumin level indicates poor prognosis of COVID-19 patients: hepatic injury analysis from 2,623 hospitalized cases. Sci China Life Sci 63(11):1678-1687. https://doi.org/10.1007/s11427-020-1733-4

41. Li Y, Xia L (2020) Coronavirus disease 2019 (COVID-19): role of chest CT in diagnosis and management. Am J Roentgenol 214(6):1280-1286. https:// doi.org/10.2214/AJR.20.22954

42. Long C, Xu H, Shen Q, Zhang X, Fan B, Wang C, Zeng B, Li Z, Li X, Li H (2020) Diagnosis of the coronavirus disease (COVID-19): rRT-PCR or CT? Eur J Radiol 126:108961-108961. https://doi.org/10.1016/j.ejrad.2020.108961

43. Kovács A, Palásti P, Veréb D, Bozsik B, Palkó A, Kincses ZT (2021) The sensitivity and specificity of chest CT in the diagnosis of COVID-19. Eur Radiol 31(5):2819-2824. https://doi.org/10.1007/s00330-020-07347-x

44. Bhayana R, Som A, Li MD, Carey DE, Anderson MA, Blake MA, Catalano O, Gee MS, Hahn PF, Harisinghani M, Kilcoyne A, Lee SI, Mojtahed A, Pandharipande PV, Pierce TT, Rosman DA, Saini S, Samir AE, Simeone JF, Gervais DA, Velmahos G, Misdraji J, Kambadakone A (2020) Abdominal imaging findings in COVID-19: preliminary observations. Radiology 297(1): E207-E215. https://doi.org/10.1148/radiol.2020201908

45. Thuluva SK, Zhu H, Tan MML, Gupta S, Yeong KY, Cheong Wah ST, Lin L, Yap ES (2020) A 29-year-old male construction worker from India who presented with left-sided abdominal pain due to isolated superior mesenteric vein thrombosis associated with SARS-CoV-2 infection. Am J Case Rep 21:e926785. https://doi.org/10.12659/AJCR.926785

46. Ibrahim YS, Karuppasamy G, Parambil JV, Alsoub H, Al-Shokri SD (2020) Case Report: Paralytic ileus: a potential extrapulmonary manifestation of severe COVID-19. Am J Trop Med Hyg 103(4):1600-1603. https://doi.org/10.4269/a jtmh.20-0894

47. Martínez-Castaño I, Calabuig-Barbero E, Gonzálvez-Piñera J, López-Ayala JM (2020) COVID-19 infection is a diagnostic challenge in infants with ileocecal intussusception. Pediatr Emerg Care 36(6):e368. https://doi.org/10.1097/PEC. 0000000000002155

48. Effenberger M, Grander C, Fritsche G, Bellmann-Weiler R, Hartig F, Wildner S, Seiwald S, Adolph TE, Zoller H, Weiss G, Tilg H (2020) Liver stiffness by transient elastography accompanies illness severity in COVID-19. BMJ Open Gastroenterology 7(1):e000445. https://doi.org/10.1136/bmjgast-2020-000445

49. Zhang H, Li HB, Lyu JR, Lei XM, Li W, Wu G, Lyu J, Dai ZM (2020) Specific ACE2 expression in small intestinal enterocytes may cause gastrointestinal symptoms and injury after 2019-nCoV infection. International journal of infectious diseases : IJID : official publication of the International Society for Infectious Diseases 96:19-24. https://doi.org/10.1016/j.ijid.2020.04.027

50. Ignat M, Philouze G, Aussenac-Belle L, Faucher V, Collange O, Mutter D, Pessaux P (2020) Small bowel ischemia and SARS-CoV-2 infection: an underdiagnosed distinct clinical entity. Surgery 168(1):14-16. https://doi. org/10.1016/j.surg.2020.04.035

51. Carnevale S, Beretta P, Morbini P (2020) Direct endothelial damage and vasculitis due to SARS-CoV-2 in small bowel submucosa of COVID-19 patient with diarrhea. J Med Virol 93(1):61-63. https://doi.org/10.1002/jmv.2 6119

52. Stahl K, Bräsen JH, Hoeper MM, David S (2020) Direct evidence of SARSCoV-2 in gut endothelium. Intensive Care Med 46(11):2081-2082. https:// doi.org/10.1007/s00134-020-06237-6

53. Tian S, Xiong Y, Liu H, Niu L, Guo J, Liao M, Xiao S-Y (2020) Pathological study of the 2019 novel coronavirus disease (COVID-19) through postmortem core biopsies. Mod Pathol 33(6):1007-1014. https://doi.org/10.1 038/s41379-020-0536-X

54. Sonzogni A, Previtali G, Seghezzi M, Grazia Alessio M, Gianatti A, Licini L, Morotti D, Zerbi P, Carsana L, Rossi R, Lauri E, Pellegrinelli A, Nebuloni M (2020) Liver histopathology in severe COVID 19 respiratory failure is suggestive of vascular alterations. Liver Int 40(9):2110-2116 https://doi.org/1 $0.1111 /$ liv. 14601

55. Lagana SM, Kudose S, luga AC, Lee MJ, Fazlollahi L, Remotti HE, Del Portillo A, De Michele S, de Gonzalez AK, Saqi A, Khairallah P, Chong AM, Park H, Uhlemann A-C, Lefkowitch JH, Verna EC (2020) Hepatic pathology in patients dying of COVID-19: a series of 40 cases including clinical, histologic, and virologic data. Mod Pathol 33(11):2147-2155. https://doi.org/10.1038/ s41379-020-00649-x

56. Fiel MI, El Jamal SM, Paniz-Mondolfi A, Gordon RE, Reidy J, Bandovic J, Advani R, Kilaru S, Pourmand K, Ward S, Thung SN, Schiano T (2020) Findings of severe hepatic severe acute respiratory syndrome coronavirus-2 infection. Cell Mol Gastroenterol Hepatol 11(3):763-770. https://doi.org/10.1 016/j.jcmgh.2020.09.015

57. Almario CV, Chey WD, Spiegel BMR (2020) Increased risk of COVID-19 among users of proton pump inhibitors. Am J Gastroenterol 115(10):17071715. https://doi.org/10.14309/ajg.0000000000000798

58. Wu J, Song S, Cao H-C, Li L-J (2020) Liver diseases in COVID-19: etiology, treatment and prognosis. World J Gastroenterol 26(19):2286-2293. https:// doi.org/10.3748/wjg.v26.i19.2286

59. Rubin DT, Feuerstein JD, Wang AY, Cohen RD (2020) AGA Clinical Practice Update on Management of Inflammatory Bowel Disease During the COVID19 Pandemic: Expert Commentary. Gastroenterology 159(1):350-357. https:// doi.org/10.1053/j.gastro.2020.04.012

60. Brenner EJ, Ungaro RC, Gearry RB, Kaplan GG, Kissous-Hunt M, Lewis JD, Ng SC, Rahier J-F, Reinisch W, Ruemmele FM, Steinwurz F, Underwood FE, Zhang X, Colombel J-F, Kappelman MD (2020) Corticosteroids, but not TNF antagonists, are associated with adverse COVID-19 outcomes in patients with inflammatory bowel diseases: results from an international registry. Gastroenterology 159(2): 481-491.e3. https://doi.org/10.1053/j.gastro.2020.05.032

61. Ellison CA, Blackwell SB (2020) Acute hepatocellular injury associated with azithromycin. J Pharm Pract 34(3):493-496. https://doi.org/10.1177/08971 90019894428

62. Makin AJ, Wendon J, Fitt S, Portmann BC, Williams R (1994) Fulminant hepatic failure secondary to hydroxychloroquine. Gut 35(4):569-570. https:// doi.org/10.1136/gut.35.4.569

63. Liu J, Cao R, Xu M, Wang X, Zhang H, Hu H, Li Y, Hu Z, Zhong W, Wang M (2020) Hydroxychloroquine, a less toxic derivative of chloroquine, is effective in inhibiting SARS-CoV-2 infection in vitro. Cell Discovery 6(1):16. https://doi.org/10.1038/s41421-020-0156-0

64. Huang C, Wang Y, Li X, Ren L, Zhao J, Hu Y, Zhang L, Fan G, Xu J, Gu X, Cheng Z, Yu T, Xia J, Wei Y, Wu W, Xie X, Yin W, Li H, Liu M, Xiao Y, Gao H, Guo L, Xie J, Wang G, Jiang R, Gao Z, Jin Q, Wang J, Cao B (2020) Clinical features of patients infected with 2019 novel coronavirus in Wuhan, China. Lancet 395(10223):497-506. https://doi.org/10.1016/S0140-6736(20)30183-5

65. Wong GL-H, Wong WW-S, Thompson A, Jia J, Hou J, Lesmana CRA, Susilo A, Tanaka Y, Chan W-K, Gane E, Ong-Go AK, Lim S-G, Ahn SH, Yu M-L, Piratvisuth T, Chan HL-Y (2020) Management of patients with liver derangement during the COVID-19 pandemic: an Asia-Pacific position statement. The Lancet Gastroenterology \& Hepatology 5(8):776-787. https:// doi.org/10.1016/S2468-1253(20)30190-4

66. Ganne-Carrié N, Fontaine H, Dumortier J, Boursier J, Bureau C, Leroy V, Bourlière M, Afef FAftSotL (2020) Suggestions for the care of patients with liver disease during the Coronavirus 2019 pandemic. Clin Res Hepatol Gastroenterol 44(3):275-281. https://doi.org/10.1016/j.clinre.2020.04.001

67. Dorrell RD, Dougherty MK, Barash EL, Lichtig AE, Clayton SB, Jensen ET (2020) Gastrointestinal and hepatic manifestations of COVID-19: a systematic review and meta-analysis. JGH Open 5(1):107-115. https://doi.org/10.1002/jgh3.12456

68. Abdelzaher H, Saleh BM, Ismail HA, Hafiz M, Gabal MA, Mahmoud M, Hashish S, Gawad RMA, Gharieb RY, Abdelnaser A (2020) COVID-19 genetic and environmental risk factors: a look at the evidence. Front Pharmacol 11: 579415-579415. https://doi.org/10.3389/fphar.2020.579415

69. Mao R, Qiu Y, He J-S, Tan J-Y, Li X-H, Liang J, Shen J, Zhu L-R, Chen Y, lacucci M, Ng SC, Ghosh S, Chen M-H (2020) Manifestations and prognosis of gastrointestinal and liver involvement in patients with COVID-19: a systematic review and meta-analysis. The Lancet Gastroenterology \& Hepatology 5(7):667-678. https://doi.org/10.1016/\$2468-1253(20)30126-6

70. Zimmermann P, Curtis N (2020) Why is COVID-19 less severe in children? A review of the proposed mechanisms underlying the age-related difference in severity of SARS-CoV-2 infections. Arch Dis Child 106(5):429-439. https:// doi.org/10.1136/archdischild-2020-320338

71. Zhou Z, Zhao N, Shu Y, Han S, Chen B, Shu X (2020) Effect of gastrointestinal symptoms in patients with COVID-19. Gastroenterology 158(8):2294-2297. https://doi.org/10.1053/j.gastro.2020.03.020

72. Agrawal H, Das N, Nathani S, Saha S, Saini S, Kakar SS, Roy P (2020) An assessment on impact of COVID-19 infection in a gender specific manner. Stem Cell Rev Rep 17(1):94-112. https://doi.org/10.1007/s12015-020-10048-z 
73. Hajifathalian K, Krisko T, Mehta A, Kumar S, Schwartz R, Fortune B, Sharaiha RZ, group* W-Gr (2020) Gastrointestinal and hepatic manifestations of 2019 novel coronavirus disease in a large cohort of infected patients from New York: clinical implications. Gastroenterology 159(3):1137-1140.e1132. https:// doi.org/10.1053/j.gastro.2020.05.010

74. Chen R, Yu Y-L, Li W, Liu Y, Lu J-X, Chen F, Zhou Q, Xia Z-Y, Gao L, Meng QT, Ma D (2020) Gastrointestinal symptoms associated with unfavorable prognosis of COVID-19 patients: a retrospective study. Front Med (Lausanne) 7:608259-608259. https://doi.org/10.3389/fmed.2020.608259

75. Zingone F, D'Odorico A, Lorenzon G, Marsilio I, Farinati F, Savarino EV (2020) Risk of COVID-19 in celiac disease patients. Autoimmun Rev 19(10):102639102639. https://doi.org/10.1016/j.autrev.2020.102639

76. lavarone M, D'Ambrosio R, Soria A, Triolo M, Pugliese N, Del Poggio P, Perricone G, Massironi S, Spinetti A, Buscarini E, Viganò M, Carriero C, Fagiuoli S, Aghemo A, Belli LS, Lucà M, Pedaci M, Rimondi A, Rumi MG, Invernizzi P, Bonfanti P, Lampertico P (2020) High rates of 30-day mortality in patients with cirrhosis and COVID-19. J Hepatol 73(5):1063-1071. https:// doi.org/10.1016/j.jhep.2020.06.001

77. Ji D, Qin E, Xu J, Zhang D, Cheng G, Wang Y, Lau G (2020) Non-alcoholic fatty liver diseases in patients with COVID-19: a retrospective study. J Hepatol 73(2):451-453. https://doi.org/10.1016/j.jhep.2020.03.044

78. Liu J, Wang T, Cai Q, Sun L, Huang D, Zhou G, He Q, Wang F-S, Liu L, Chen J (2020) Longitudinal changes of liver function and hepatitis B reactivation in COVID-19 patients with pre-existing chronic hepatitis B virus infection. Hepatol Res 50(11):1211-1221. https://doi.org/10.1111/hepr.13553

79. Singh S, Khan A (2020) Clinical characteristics and outcomes of coronavirus disease 2019 among patients with preexisting liver disease in the United States: a multicenter research network study. Gastroenterology 159(2):768771.e3. https://doi.org/10.1053/j.gastro.2020.04.064

80. Hashimoto T, Perlot T, Rehman A, Trichereau J, Ishiguro H, Paolino M, Sigl V, Hanada T, Hanada R, Lipinski S, Wild B, Camargo SMR, Singer D, Richter A, Kuba K, Fukamizu A, Schreiber S, Clevers H, Verrey F, Rosenstiel P, Penninger JM (2012) ACE2 links amino acid malnutrition to microbial ecology and intestinal inflammation. Nature 487(7408):477-481. https://doi.org/10.1038/ nature 11228

81. Kaur H, Shekhar N, Sharma S, Sarma P, Prakash A, Medhi B (2021) Ivermectin as a potential drug for treatment of COVID-19: an in-sync review with clinical and computational attributes. Pharmacol Rep 73(3):1-14. https://doi. org/10.1007/s43440-020-00195-y

82. Fox LM, Saravolatz LD (2005) Nitazoxanide: a new thiazolide antiparasitic agent. Clin Infect Dis 40(8):1173-1180. https://doi.org/10.1086/428839

83. Aygün I, Kaya M, Alhajj R (2020) Identifying side effects of commonly used drugs in the treatment of Covid 19. Sci Rep 10(1):21508. https://doi.org/10.1 038/s41598-020-78697-1

84. Du Y-X, Chen X-P (2020) Favipiravir: pharmacokinetics and concerns about clinical trials for 2019-nCoV infection. Clinical Pharmacology \& Therapeutics 108(2):242-247 https://doi.org/10.1002/cpt.1844

85. Okuno H, Takasu M, Kano H, Seki T, Shiozaki Y, Inoue K (1993) Depression of drug-metabolizing activity in the human liver by interferon- $\beta$. Hepatology (Baltimore, Md) 17(1):65-69 https://doi.org/10.1002/hep.1840170113

86. Horby PW, Mafham M, Bell JL, Linsell L, Staplin N, Emberson J, Palfreeman A, Raw J, Elmahi E, Prudon B, Green C, Carley S, Chadwick D, Davies M, Wise MP, Baillie JK, Chappell LC, Faust SN, Jaki T, Jefferey K, Lim WS, Montgomery A, Rowan K, Juszczak E, Haynes R, Landray MJ (2020) Lopinavir-ritonavir in patients admitted to hospital with COVID-19 (RECOVERY): a randomised, controlled, open-label, platform trial. Lancet 396(10259):1345-1352. https:// doi.org/10.1016/S0140-6736(20)32013-4

87. Wang M, Cao R, Zhang L, Yang X, Liu J, Xu M, Shi Z, Hu Z, Zhong W, Xiao G (2020) Remdesivir and chloroquine effectively inhibit the recently emerged novel coronavirus (2019-nCoV) in vitro. Cell Res 30(3):269-271. https://doi. org/10.1038/s41422-020-0282-0

88. Tong S, Su Y, Yu Y, Wu C, Chen J, Wang S, Jiang J (2020) Ribavirin therapy for severe COVID-19: a retrospective cohort study. Int J Antimicrob Agents 56(3):106114-106114. https://doi.org/10.1016/j.ijantimicag.2020.106114

89. Khan NA (2020) Anakinra for severe forms of COVID-19. The Lancet Rheumatology 2(10):e586-e587. https://doi.org/10.1016/S2665-9913(20)3 0273-3

90. Richardson P, Griffin I, Tucker C, Smith D, Oechsle O, Phelan A, Rawling M, Savory E, Stebbing J (2020) Baricitinib as potential treatment for 2019-nCoV acute respiratory disease. Lancet 395(10223):e30-e31. https://doi.org/10.101 6/50140-6736(20)30304-4
91. La Rosée F, La Rosée P (2020) Ruxolitinib in COVID-19 hyperinflammation and haematologic malignancies. Acta Haematol 144(3):246-249. https://doi. org/10.1159/000510770

92. Khiali S, Rezagholizadeh A, Entezari-Maleki T (2020) A comprehensive review on sarilumab in COVID-19. Expert Opin Biol Ther 21(5):1-12. https://doi. org/10.1080/14712598.2021.1847269

93. Chen L-F, Mo Y-Q, Jing J, Ma J-D, Zheng D-H, Dai L (2017) Short-course tocilizumab increases risk of hepatitis $B$ virus reactivation in patients with rheumatoid arthritis: a prospective clinical observation. Int J Rheum Dis 20(7):859-869 https://doi.org/10.1111/1756-185X.13010

\section{Publisher's Note}

Springer Nature remains neutral with regard to jurisdictional claims in published maps and institutional affiliations.

\section{Submit your manuscript to a SpringerOpen ${ }^{\circ}$ journal and benefit from:}

- Convenient online submission

- Rigorous peer review

- Open access: articles freely available online

- High visibility within the field

- Retaining the copyright to your article

Submit your next manuscript at $\boldsymbol{\nabla}$ springeropen.com 